3225 воября 1992 г. резолюпией 47/33 Генераљвая Ассамблея ООН поручила КМП в первоочередном поряцке заняться разработкой проекта статута мехиународного уголовного суда. Одновременно и независимо ог деятельво ти КМП в этой области в ООН обсухдается вотрос об учрежиении Мехдународвого уголовного трибунала для рассмотрения дел о преступлениях, совершеннах на территорин бывшей Югославнн.

\title{
МЕЖДУНАРОДНОЕ ПРАВО И МИРОВОЙ ПОРЯДОК
}

\author{
A.П. Мов у ан *
}

Эти понятия ("мировой порядок" в особенности) постоянно звучат в последнее время в заявлениях и выступлениях руководителей государств и ведомств иностранных дел, а также известных политических деятелей. Этими терминами ныне часто оперируют журналисты и публицисты.

Формула "мировой порядок" становится привычной для нас, и мы перестаем задумываться над тем, а что же она в действительности означает. Важны ли подобные размышления? Видимо, да, важны, поскольку в конечном счете речь идет о том порядке в мире, в котором нам приходится или предстоит жить.

Новым импульсом к подобным раздумьям послужило выдвижение президентом Дж. Бушем идеи "нового мирового порядка". У политиков и комментаторов сразу же возник вопрос: что означает эта концепџия - новый политический курс CIIA, претензию на неогрангqенное лидерство в мире или же стремление к обеспечению "мира во всем мире"? В частности, лондонская "Гардиан" попросила широкоизвестных деятелей и ученых из разных стран высказатъ свое мнение относительно "нового мирового порядка". И все они в той или иной степени указали на то, что этому понятио может быть придан самый противоположный политический смысл ${ }^{2}$. В свою очередъ, Совет взаимодействия (международная организация бывших глав государств и прввительств) в результате анализа ситуащии, возникшей в мире после окончания "холодной войны", пришел к выводу о том, что"грозящие миру критические проблемы глобального характера требуют пересмотра международных отношений и выработхи вового определения мирового порядка (выделено мною. - A. М.)"2 .

Концепция и понятие мирового порядка относительно новы. Известные исследователи миропорядка считают, что сам этот термин впервые был употреблен в документах "Группы 77" развиваюшихся стран, то есть "родился в недрах практической политики". Вскоре "миропорядок стал предметом пристального внимания ученых", однако среди них "наблюдается огромный разнобой в подходе $k$ понятио миропорядка"3.

* Доктор юридических наук, профессор. 
Действительно, подходы не только ученых (политологов, экономистов, философов, юристов и др.), но и политических деятелей К пониманию сущности мирового порядка настолько разноречивы, что с трудом поддаются какому-либо обобщению. Все же, несмотря на эти различия, которые наблюдаются даже в рамках одной монографической публикации, не говоря уже о-сборниках статей, посвященных анализу мирового порядка ${ }^{4}$, можно заметить, что в большинстве случаев в них исследуется лишь существующее положение дел в мире, констатируется сложившаяся международная ситуация, которая воспринимается и оценивается как определежный мировой порядок.

Такое видение миропорядка нередко приводит к парадоксам. Например, наиболее распространенным было мнение о том, что решающим фактором в международных отношениях служит мощь государств, включая их военный потенциал и вооруженные силы. Мировой порядок поэтому трактовался как состояние динамического соответствия международных отношений соотношению сил на мировой арене, в первую очередь между СССР и США как двумя "сверхдержавами". Следовательно, господство силы или стремление к балансу сил, постоянно порождающие соперничество между государствами и гонку вооружений, выдввались за определенный мировой порядок. Прекращение существования Советского Союза и соответственно биполярного мира неизбежно означвло крушение данного "прагматичного" видения мирового порядка. Оказались несостоятельными и попытки выдать состояние "холодной войны" $3 а$ определенный "порядок" дел в мире. Окончание "холодной войны" невольно означало в свете указанного подхода прекращение существования мирового порядка и, следовательно, наступление беспорядKa.

О том, что такой подход был широко распространенным, говорит и упомянутое выше заявление Совета взаямодействия, в котором необходимость выработки нового понимания мирового порядка объясняется окончанием "холодной войны". Нельзя также не заметить, что ее прекращение создало эатруднения и для тех политологов, которые постулировали постоянное противостояние между Востоком и Западом в силу существенных различий и расхождений между социальньми системами и классовьми установками государств и на основе этой конфронтащии конструировали свое видение нынешнего и грядущего миропорядка. Новейшие договоренности между Востоком и Западом, в том числе и в области разоружения, совместные шаги государств - участников СБСЕ по включению мер обеспечения "демократии и верховенства закона" в число мероприятий, содействуюших укреплению безопасности в Европе и во всем 
мире, в конечном суете подтвердили некорректность или несостоятельность подобного рода моделей мирового порядка.

К сожалению, характерное для многих прежних публикаций по вопросам миропорядка стремление ограничиться при формулировании концепции и понятия мирового порядка лишь отражением и описанием существующего состояния мировых отношений, сложившейся международной практики присуще также в определенной мере и уже появившимся в прессе суждениям относительно нового мирового поряпка. Многие из них завершаются спасительной ссылкой на то, что еще рано давать какие-либо рекомендации и оценки, ибо надо подождать развития событий в современном сложном многополярном мире. Но такая пассивностъ противоречит даже той логической и смысловой нагрузке, которая должна содержаться в понятии "мировой порядок". Ведь к несомненной заслуге исследователей миропорядка следует отнести их постоянное предупреждение о том, что порядок в мире необходимо рассматривать не только как политическую реальность, но и как идеал или цељь, к достижению которой должны стремитъся все государства в мире. Поэтому понятие "мировой порядок" должно охватывать и отражать реальную действительность, а также и глобальную задачу обеспечения порядка во всем мире.

Любая концепция мирового поряпка не может не принимать во внимание и такое новое явление наших дней, как "международное сообщество государств". Этот институт, возникший после окончания второй мировой войны и проявившийся впервые в создании ООН, находится в процессе постоянного развития и укрепления, олицетворяя высокую степень взаимосвязанности и взаимозависимости госу дарств в современном мире. Упоминание о международном или мировом сообществе присуще исследованиям проблем миропорядка, но оно почему-то не учитьвалось при окончательном формулировании понятия и определения "мировой порядок".

И еще над одним из вопросов заставляют задуматься работы специалистов по миропорядку. В них зачастую подчеркивается, что понятия "мировой порядок" и "международный порядок" не совпадают. И это пояснение кажется на первый взгляд справедливым. Однако в дальнейшем замечаешь, чло даже в научных публикациях, содержащих такое предупреждение, оно последовательно не соблюдается и не выдерживается. Так, например, весьма содержательная работа о международном порядке, опубликованная в нашей литературе, предваряется введением, в котором рець идет о мировом порядке, но его понятие тесно увязывается с сущностью и развитием порядка в международных отношениях ${ }^{5}$. Это же характерно и для зарубежных публикаций ${ }^{6}$. В них, как правило, применяется термин "мировой порядок". Но предметом основного внимания ав- 
торов служат только международные отношения и международный порядок. Что же касается весьма широкой практики применения термина "мировой порядок" официяльными деятелями государств, то тут уж, вне всяких сомнений, имеется в виду именно порядск в международных делах, в международных отночсниях. Достєточно сослаться на концепцию "нового мирового порядка" президента Дж. Буша и отклики на нее как политических деятелей, так и ученых, чтобы убедиться в том, что речь идет о порядке во взаимоотношениях государств, известных современной политической карте мира.

Отрадно отметить, что в дискуссиях по поводу нового мирового порядкв все чаще стали встречаться ссылки на международное право и на Устав ООН как универсальный кодекс права для всего международного сообщества, на механизмы поддержания правопорядка под эгидой ООН. Да и в выступлениях Дж. Буша говорится о новом мировом порядке, "основанном на международном праве". Все это в значитељьнй мере облегчает пояснение и обоснование нашего подхода к понятию мирового порядка, центральное место в котором принадлежит, конечно же, термину "порядок".

В общеупотребительном смысле слово "порядок" означает правильное, налаженное состояние. Применительно к общественным отношениям оно толкуется как режим и правила, по которым осуществляются эти отношения. Словарь Вебстера идет еще дальше в конкретизации термина "порядок", считая, что он подразумевает состояние мира и спокойствия, надлежащее "упорядоченное" поведение, "соблюдение права".

В теории права, несмотря на самые различные и подчас противоположные объяснения происхождения и сушности права, всегда суиествовало общее понимание, что назначение права состоит в том, чтобы и создать, и обеспечить общественный порядок. В повседневной реальной жизни "право для людей всегда выступало как определенный порядок в обшестве (курсив мой.- А. М.)"7. При этом в исследованиях по теори права справедливо подчеркивается, что "прн любом подходе к праву в нем признается определенный общественный порядок, право выступает в качестве общественного регулятора, обеспечивающего порядок в обществе. Это вне сомнений"8.

Применительно к международному сообществу государств понятие "порядок" также должно отвечать сложившимся представлениям об этом термине $и$, следовательно, означать определенный порядок в отношениях между государствами, предусмотренный и установленный международным прввом. Международный Суд ООН неоднократно обращал внимание на эту сошиальную ценность между- 
народного права как "юридического здания, бережно возводимого человечеством веками", и отмечал, что весьма сложное современное международное сообщество "как никогда нуждается в том, чтобы постоянно и тщательно соблюдались нормы, которые были созданы для обеспечения упорядоченных отношений (курсив мой.- А.М.) между государствами - членами сообщества"9.

В новейших исследованиях современной теории права констатируется тот исторический факт, что "развитие человеческой цивилизации все больше и бољше направляется $к$ практическому от ходу от конфронтации людей и народов к их сосуществованию, согласию и компромиссу" ${ }^{\circ}$. С учетом этой тенденции доктрина права постепенно признает право в качестве средства общественного согласия. "В этом понимании право является стстемой обществевного порящка, основанной на учете ннтересов разных слоев общества,

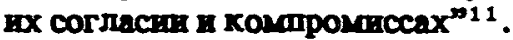

Но ведь это постепенно утверждающееся свойство права всегда было присуще международному праву, поскольку все его нормы возникают и существуют лишь в результате согласия, соглашения различных государств, основанного на учете их интересов и компромиссах. Поэтому, учитывая созидательные, жизненные истоки юридических правил международного общения государств и реальное нязначение этих норм в международных отношениях, являюшихся одним из видов общественных отношений, нељьзя не прийти к выводу о том, что и международное право представляет собой систему общественного порядка в современном мире, то есть мирового порядка.

Этот вывод подкрепляется и позпнейшими исследованиями в теории международного права и правопорядка. В работах юристовмеждународников разных стран все чаще стала рассматриваться и оцениваться роль международного права в обеспечении порядка в междунаропных отношениях. При этом характерна трактовка международного права как олищетворения "международного публичного порядкя"12 или же "нормативного порядка"13. Правопорядок в международном сообществе понимается как "порядок отношений, который установлен и осуществляется на основе принципов и норм международного права"14, либо как "совокупность отношений, основанных на нормах права"15, или же как "совокупность правоотношений, которые складываются в соответствии с нормами и предписаниями международного права" 16 .

При этом иногда высказывается мнение, что "миропорядок не сводится только к международному правопорядку. Однако международный правопорядок составляет основу, главное содержание миропорядка" ${ }^{17}$. К сожаленио, такое замечанне не сопровождает- 
ся каким-либо пояснением. По-видимому, авторы считакт его само собою разумеюшимся. Может быть, это и так. Но все же возникает вполне оправданный интерес к тому, чтобы узнать, а что же все-таки находится за предепами пра́вопорядка, но входит в миропорядок? В чем суцность этого в некотором роде "остатка", ибо он не является "главным содержанием миропорядка" и не охватывается международным правом как системой общественного поряпка? А может быть, такой "остаток" относится уже не к поряпку, а к беспоряпку и мы лишь по инерщии продолжаем относить $к$ миропорядку все происходящее на международной арене, в том qисле и не соответствующее или даже противоречащее междунаропному праву либо еще не "упорядоченное" с помошью международного права? Чтобы разобраться в этом, необходимо провести хотя бы краткий анализ тех сущностных черт международного права, которые, по нашему мнению, содействуют пониманию и определению такого сложного общественного явления, Как мировой порядок.

Прежде всего целесообразно констатировать тот факт, что современное междунаропное право по своему содержанию охватывает практицески почти все виды деятельности государств на междунарощной арене, их взаммоотношений и сотрудничества в самых различных сферах международной жизни, как традиционно сложившихся, так и в новых сферах, обусловленных обшественно-экономическим и научно-техническим прогрессом. Междунаропный Суд еще в первые годы своей деятельости подчеркнул, что "вся история международного права свидетельствует о том, что оно развивается под влиянием требований жизни"18. При этом, как справедливо подметил Г.И. Тункин, "междунаропное право не только следует за развитием отношений между государствами и упорядочивает их, но и нередко имеет целью регулирование возможных в бупущем отношений между государствами"19. В качестве примера приводит ся космическое право, которое не ограничивается регулированием существуюших отношений, а стремится создать возможности для регламентации новых отношений в будущем. В этой связи Ю.М. Колосов вполне обоснованно указывает на то, что принципы космического права, учитываюшие интересы всех государств, в том qисле и не осуществляоших космической деятельности, "можно рассматривать Как один из факторов нового миропорядка (курсив мой. A.M.)"20. Такое же стремление, на наш взгляд, было характерно и для государств - участников III Конференци ООН по морскому праву при осуществленин ими копнфнкащин и прогрессивного развития современного междунаропного морского права.

Здесз уместно привести данные Секретариата ООН о том, что за первые 35 лет существования ООН ее органами или конференциями 
под ее эгидой было разработано около 200 многосторонних договоров по кодификащии и дальнейшему развитио общего международного права ${ }^{21}$. Такая успешная работа позволила в свое время Генеральному секретарю ООН Пересу де Куэльяру указать на то, что с помощью ООН "значительно большая часть международного права" была кодифицирована и развита, чем "за всю предыдущую историю человечества"22. Благодаря такой интенсивной международной нормотворческой деятельности государств общее международное право обогатилось многими новыми принципами и нормами, которые в сумме своей свидетельтвуют о том, что в его предметном содержании произошел значитељный качественный скачок. Оно стало охватывать, в сушности, все виды взаимосогласованной деятельности государств, их взаимоотношений и совместного сотрудничества, которые известны современной практике международных отношений.

Наряду с нормами общего международного правя в международных отношениях создаются и действуют локальные нормы международного правя, в основном договорные по своему происхождению и характеру. Они служат урегулированию тех спешифических проблем международных отношений, которые, по мнению государств участников локальных международных договоров, не упорядочены В достаточной мере принципами и нормами общего международного права ${ }^{23}$. В связи с этим сложилось и утвердилось понимание современного междунаропного права как охватывающего общее международное право и локальные международные нормы. Поэтому официальная практика государств ныне ограничивается применением термина "международное право" для обозначения всей системы международных принципов и норм, юридически обязатељьных для всех без исключения государств. Весьма характерна для современной дипломатической практики и постоянная ссылка на междунаропное право при оценке фактически любой ситуации, возникающей в отношениях между государствами. Это также говорит о весьма высоком содержательнм уровне действующего международного права.

Наконец, оценивая содержание международного права, нељзя не отметить общедемократический характер его принципов и норм. В силу этого они общеприемлемы для всех участников международных отношений, в том числе для государств с различньми сошиальными системами. С претворением в международно-правовую жизнь идеи мирного сосуществования государств "независимо от их политических, экономических и социяльных систем и от уровня их развития" (Декларация ООН о приншипах международного права 1970 г.) международное право стало подлинно универсальньм. 
Вследствие распада колониальной системы расширилась также пространственная сфера действия международного права. "Оно стало в этом смысле всемирным правом" 24 .

Таким образом, сочетание весъма развитой содержательной системы международно-правовых принципов и норм со всемирным масштабом их действия свидетельствует о том, что современвое мехдународное право представляет собой делостнуп спстеау общественного порядка в мире, то есть мировой порядок, которому должны следовать и в основном уже практически следуют все участники современных междунаропных отношений.

Однако международная жизнь настолько многообразна, что многие явления в ней остаются и будут оставаться за пределами действия норм международного права. К их числу, несомненно, относятся факторы, влияюшие на формирование внешней политики государств, на внешнеполитическую тактику и стратегию отдельных государсте или групп государств. Выбор ненасильственных дипломатических средств и приемов для реализащии внешнеполитической позиции государств, уровенъ и характер их политико-экономических отношений и сотрудничества с теми или иными государствами вплоть до установления тесных сожозических взаимоотношений, конечно, не охватываются предписаниями международного права. Такие внешнеполитидеские шаги и мероприятия конкретных государств предпринимаются ими с учетом потребностей политического и экономического развития, степени достигнутого участия во всемирных отношениях, специфики интересов, обусловленных принадлежностью к определенному региону, например к Европе или Ближнему Востоку, и многими иньми факторами, которые не поддаются исчерпывающему перечислению. Все они в сумме своей определякот сущность и характер мировой политики, которая, в свою очередь, оказывает огромное воздействие на состояние дел в мире, на мировой порядок.

Эту сферу политической реальности имеют, вероятно, в виду исследователи миропорядка, когда предупреждағт о том, что понятие мирового порядка шире понятия правопоряпка в международных отношениях. Но можно и следует ли такие факторы и обусловленные ими внешнеполитические акции государства или групп государств считать элементами мирового порядка? Не составляют пи они содержание и сушносъ иных общественных явлений междунвродной жизни, которые подпадают под понятия "внешняя политика" или "мировая политика"?

Более того, если, как признают и специелисты по мнропорядку, "порядок существует только при нормативном поведении"25, тогда все внешнеполитические действия и акция государств или групп 
государств, не соответсгвуюшие нормам международного права, в тем более противоречвщие им, вообще не могут считаться "нормативным поведением" и, следовательно, охватываться понятием или термином "мировой порядок". Стоит только оглянуться на внешнеполитическую практику недавнего прошлого, чтобы увидеть, как две "сверхдержавы", уповая на свою зоенно-политическую мошь и военно-политические союзы с группами спределенных государств, оказывали огромное воздействие на внешнюю политику всех других государств и на мировую политику в целом. При этом нередко игнорировались интересы народов многих стран и элементарные юридические правиля международных отношений. Но разве можно такие акции "псдгонять" под понятие "мировой порядок"?

Международнсе сообщество государгтв еще в 1945 году было уполномочено на основании главы VII Устава ОOH применять принудительные меры в оттошении действий государств, представляющих любую угроэу миру, нарушение мира или акт агрессии. Такое принуждение не считалось затрагивающим принцип невмешательства во внутренние дела государств (п. 7 ст. 2 Устава ООН). Это положение сохраняет свое значение и в наши дни: любая внешнеполитическая акция, представляющая собой угрозу силой или ее применение, несовместима с целями и принципами ООН и подлежит пресечению согласно предписаниям действующего международного права. Для нашего времени харахтерна и тенденция расширения сферы международно-правового регулирования, под которое подпадают вопросы, ранее считавшиеся внутренним делом государств, в числе которых - вопросы прав человека, охраны окружающей среды. Внешние дела, связанные с нарушением предписаний международного права, также стали предметом озабоченности международного сообщества государств в целом, которое вправе принять меры К устранению нарушений международной законности, к пресечению международных преступлений. Поэтому привычное для дипломатического лексикона выражение "невмешательство во внутренние и внешние дела государств" уже больше не отражвет международно-правовую действительность. Более точной и хорректной сегодня следует признать формулировку относительно иевмешательства "во внутренние или внешние дела, входящие во внутреннюю компетенцию" государств, которая была закреплена в хельсинкском Заключительном акте.

पто касвется внешнеполитических акций государств по вопросам, еще не урегулированным международным правом, то история международных отношений содержит много примеров того, Как государства вынуждены были либо сами стремились отразить и звкрепить в нормах международного права свою позицию, с тем чтобы обеспечить ее устойчивое восприятие другими государствами и 
таким образом создать и установить определенный порядок поведения государств в конкретной сфере международной жизни. Так, односторонние действия США по распространению своих суверенных прав на континентальный шельф, а затем и некоторых развивающихся стран по подчинению своему суверенитету прибрежных пространств открытого моря, объявленных ими "рыболовными" или "экономическими" зонами, были справедливо расценены международным сообществом как произвольные действия, подрывающие сложившийся мировой порядок на морях и океанах. Возникли международные споры и конфликты, которые продолжались до тех пор, пока не было достигнуто международно-правовое признание статуса и режима континентального шельфа и исключительной экономической зоны на соответствующих многосторонних конференциях й переговорах.

Вместе с тем есть примеры и того, как государства, заннтересованные в установлении нового порядка в конкретной области международных отношений, сами выступали инициаторами создания новых международных правил и рекомендаций, отражаюших их интересы и позицию. Так, в 1974 году группа развивающихся стран выступила с программой действий по установлению нового международного экономического порядка, которая была закреплена в соответствующей Декларации и Хартии экономических прав и обязанностей государств, принятых на VI специальной сессии и XXIX регулярной сессии Генеральной Ассамблеи ООН. Новейшими примерами могут служить внешнеполитические шаги и меры европейских государств по осуществлению интеграционного процесса в Европе и заключению в этих целях международных соглашений относительно Европейского сообщества.

В этом контексте уместно упомянуть о том, что современному международному праву известна целая система международных механизмов для решения актуальных проблем и конкретных вопросов международных отношений, для нахождения и разработки общеприемлемых для всех государств соглашений и договоренностей, относящихся к тем спещифическим ситуациям, которые, по мнению государств, не получили должного и достаточного урегулирования в существуюших юридических правилах международного общения. Для современных международных отношений стало характерным не только существование постоянных действующих межгосударственных организаций (ОOH, ее специализированных учреждений и многих других межправительственных образований универсального и регионального характера), но и регулярное проведение международных встреч, консультаций, переговоров как на высшем, так и на других уровнях. Наличие и регулярное использование государствами таких интернашиональных механизмов для разрешения насуш- 
ных проблем международных отношений и международного нормотворчества составляет существенную черту современного мирового порядка.

Опыт деятельности межправительственных органов и организаций, правила процедуры их работы, порядок создания новых международно-правовых принципов и норм, в том числе и специфических правил, регламентов и стандартов (в рамках, например, ММО, ИКАО), убедительно свидетельствуют о реальной возможности достижения в наши дни оптимального сочетания наџиональных интересов государств с потребностями международного сообщества в целом. Главное при этом состоит в том, чтобы индивидуальные или групповые дипломатические инициативы и действия государств, обусловленные их национальными интересами, политико-экономической мощью и связанным С этим политико-экономическим влиянием, которое они оказывают на мировую политику, не выходили за рамки того порядка в международных отношениях, который предусмотрен в принципах и нормах международного права, тщательно создававшихся всем человечеством на протяжении его истории. Это требование в равной мере применимо ко всем государствам (и большим, и малым), а также ко всем тем многочисленным и разнообразным дипломатическим шагам и внешнеполитическим акциям различных государств, без которых немыслимы международная жизнь и мировая политика.

Динамика общественного развития не раз приводила и, несомненно, еще приведет к существенным переменам в международных отношениях и мировой политике. Богат такими событиями и $\mathrm{XX}$ век, отмеченный двумя мировыми войнами, возникновением Советского Союза, оказавшего значительное воздействие на мировую политику и соотношение сил в мире, и распадом этой "сверхдержавы", крушением колониальной системы и появлением значительной группы развивающихся стран, созданием универсальных межгосударственных организаций и связанным с этим сплочением государств в "международное сообщество" и, наконец, появлением небывалого числя независимых государств со своим самостоятельным ви́дением и подходом к международным делам и отношениям.

Немало испытаний претерпело в нынешнем столетии и международное право - от полного пренебрежения к нему в период подготовки и развязывания второй мировой войны до неоднократного его нарушения во время "холодной войны", что породило чувство вседозволенности у двух "сверхдержав", особенно проявившееся в их вооруженных интервенциях во Вьетнаме и Афганистане. Нельзя не упомянуть и о нападках на международное право со стороны отдельных политических деятелей и специалистов, начиная от "нега- 
тивистов", отрицавших какое-либо значение междунарощного права, и кончяя скептиками, высказывания которых встречаются и поныне.

Однако международное право не только выдержало свою проверку этими трудными для него временами, не только сохранило действенность всех традиционно сложившихся норм, но и обогатилось новыми принципами и нормами, вызванными потребностями меняющихся международных отношений. Создание Устава ООН и закрепление в нем основных принципов деятельности всемирной межгосударственной организации как бы констатировало переход от международного права "цивилизованных народов" к общему международному праву как системе права, отражающей общие интересы всего международного сообщества государств, а также те закономерности развития международных отношений, которые присуши современной эпохе сосуществования и сотрудничества всех государств независимо от Каких-либо их различий.

В Уставе $\mathrm{OOH}$ - важнейшем международно-правовом акте наших дней - были закреплены, в сущности, те краеугольные основы нового порядка в мире, которые служат объективными нормативными рамками и критериями для регламентации и оценки должного поведения государств в современном мире. Объединение всех государств на этих политико-правовых основах во всеобщую и универсальную международную организацию - ООН - свидетельствовало об осознании государствами той непреложной реальности нашего времени, что все страны и народы существуют на единой планете Земля и должны совместно обсуждать и находить решения всех глобальных проблем как единое мировое сообщество.

Так почему же не признать и не подтвердить сегодня тот факт, что действующее общее международное право олицетворяет собой ту выработанную мировым сообществом модель нового мирового порядка, которая отвечает интересам всех государств, требованиям современности и не была до сих пор полностью реапизована лишь из-за конфронтации между Западом и Востоком и в определенной мере из-за противоречий и разногласий между Севером и Югом?

Такой подход к оценке роли и значения общего международного права соответствует и фактически единодушному мнению специалистов по миропорядку о том, что мировой порядок необходимо рассматривать как политическую ревлию и как идеал. Под политиуеской реальностью понимается упорядоченное взвимодействие государств, а под идеалом - некая идеальная организашия междунарощной жизни ${ }^{26}$. Эти элементы понятия мирового порядка в полной мере присуши общему междунаропному праву. Оно уже упорядочило взаимодействие и сотрудничество государств во мно- 
гих сферах всемирных отношений, но по-прежнему все еще предсгеєт перед нами как определенная цель в организашим мехдународной жизни государств, К достижению которой должно стремитъся все мировое сообщество.

Целенаправленность общего междунаропного права состоит в том, чтобы обеспечить ненасильственный мир, нормальные, миролюбивые и дружественные взанмоотношения и сотрудничество между государствами в соответствии с основными принципами Устава ООН (Декларация ООН о принципах международного права 1970 г.).

Для объединения дальнейших усилий сообщества государств по достижению этой благородной цели сейчас складывается благоприятная международная обстановка. Конфронтация Восток - Запад, которая определяла деятельность ООН многие годы, ушла в прошлое. Закончившаяся в конце 1992 года 47-я сессия Генеральной Ассамблеи ООН, а также заседания Совета Безопасности в течение прошлого года показали, что практически не было существенных разногласий между государствами ни по одному из приншипиальных вопросов междундродных отношений.

Руководители государств теперь постоянно уделяют внимание междунарошному праву. Это характерно и для концепщии "нового мирового порядка", выдвинутой Вашингтоном, и для заявлений Совета НАТО, ныне регулярно призывающего к тому, чтобы "власти на всех уровнях" стали уважвть международное право, и особенно для решений, принимаемых в рамках СБСЕ. При этом даже бывшие союзники Вашингтона не склонны более полагатъся на заверения CIIIA и безоговорочно воспринимать американское лидерство в новом мировом порядке.

Показательна в этом отношении ситуация с гуманитарной акцией в Сомали. СІІА намерены были самостоятельно осуществить "гуманитарную интервенцию" в Сомали. Однако Франция проявила инициативу и настояла на том, чтобы "спасение Сомали" было осуществлено не под комвндованнем Вашингтона, а под эгидой ООН. В силу военной мощи США основную роль в Сомали по-прежнему выполняют американские вооруженкые силы, но уже с участием сил двядцати других государств и под контролем ООН. "При этом, подчеркнул министр иностранных дел Фракции Р. Дюма, - никакая страна, пусть даже самея могучвя, не должна присваңвать себе право вести себя как жандарм, восстанавливать порядоК в той или иной стране, менять ее правительство"27. Всем памятно, как прежде США по своему усмотрению осуществляли "гуманитарную интервенцию", в частности в Гренаде и Панаме, не считаясь с ООН и международным правом. Ныне американские силы применяются 
лишь для "сопровождения гуманитарной помощи" и под эгидой ООН. Это, по мнению Р. Дюма, "юридическое новшество в международной жизни"28.

В создавшихся новых условиях очевидна задача юристов-международников - раскрыть тот огромный потенциал, который был заложен учредителями $\mathrm{OOH}$ в функции и полномочия органов этой всемирной организации в интересах обеспечения нового мирового порядка по окончании второй мировой войны, но так и не был еще полность реализован. Повысилось и значение установок относитељно содействия распространению знаний о международном праве, которые характерны для многих резолюций Генеральной Ассамблеи $\mathrm{OOH}$, для уставов различных ассощиаций и объединений юристов, в том числе и для устава недавно созданного Московского независимого института международного права. Насущная потребность в этом обусловлена не столько теми юридическими пробелами или недочетами, которые подчас присущи дипломатической и договорной практике государств, особенно недавно возникших, в том числе и в результате распада Советского Союзя, сколько все возрастающим среди широких официальных и общественных кругов пониманием того факта, что ањ тернатввы мехдународному праву как фундаменту в регулятору мнрового порядка в нашп дни нет и не мохет быть.

При осуществлении этой разъяснительной работы юристамимеждународниками да и специалистами по миропорядку первостепенное внимание, по нашему мнению, должно быть уделено социальному и юридическому значению принципов Устава ООН как основных принципов междунаропного права, определяюших сошиальную и политико-правовую направленность всех действующих международных правил поведения государств, а следовательно, и целенаправленность нового мирового порядка.

Воэникновение и утверждение системы основных принципов явление, характерное для общего международного правя. Традиционному международному праву и его доктрине не было присуще выделение каких-либо норм в качестве основных принципов. Этим, видимо, объясняется сдержанное отношение западных юристов-международников к данной правовой категории и применение ими в своих публикашиях вместо понятия "основные принципы" таких терминов, как "высшие принципы", "обшие принципы" и просто "принципы"29. Для наших юристов-международников (как ученых, так и практиков) всегда характерным было применение понятия "основные принципы" и постоянное исследование их сушности и значения как наиболее важных, общепризнанных норм, составляющих идейну ю и нормативную основу всей системы международного права ${ }^{30}$. 
Объективным критерием для позитивного разрешения все еще существующих разночтений в подходе к правовой характеристике принципов Устава ООН может служить принятая в ООН на основе консенсуса Декларация о принципах международного права, касающихся дружественных отношений и сотрудничества между государствами в соответствии с Уставом Организации Объединенных Наций, 1970 года. В ней было выражено единодушное суждение международного сообщества государств о том, что "принципы Устава, содержащиеся в настоящей Декларации, представляют собой основные приниипы международного права (курсив мой. - А.M.)", и закреплен призыв к тому, чтобы все государства руководствовались этими принципами "в своей международной деятельности" и развивали свои взаимоотношения "на основе их строгого соблюдения" ${ }^{31}$.

Этот призыв, обращенный ко всем без исключения государствам, отразил ту всеобщую юридическую обязательность принципов $\mathrm{OOH}$, которая изначально была закреплена в ее Уставе. Так, например, в интересах поддержания международного мира и беэопасности $\mathrm{OOH}$ была изначально уполномочена обеспечивать, чтобы "государства, которые не являются ее членами, действовали в соответствии с этими принципами" (п. 6 ст. 2 Устава ООН). Данное постановление Устава ООН сохраняет свою актуальность, поскольку в мире продолжается процесс возникновения новых государств, не сразу становящихся членами ООН. В свое время нам уже приходилось возражать против абсолютизации концепции согласования воль государств, в силу которой считалась вполне справедливой и правомерной позиция новых государств, когда они не считали себя автоматически связанными принципами международного права, созданньми без их волеизъявления и согласия. Подобная "абсолютизация" вольно или невольно означала, что обязательность основных принципов международного права ставилась В зависимость от "поголовного" признания их юридической силы и тем самым практически вела к беспорядку в международных отношениях. Ни наука, ни практика международного права никогда не исходили из таких требований ${ }^{32}$, а тем более сейчас, когда в результате усилий международного сообщества по повышению юридического авторитета и значения принципов Устава ООН (например, положения Венской конвенции о праве международных договоров 1969 г. относительно јus cogens) доктрина и практика международного права исходят из того, что его основные принципы являются императивными нормами. В настоящее время общепризнанно, что отклонение от соблюдения этих принципов как основных правовых норм должного поведения государств и иных участников международных отношений юридически недопустимо, а подчас и преступно. В этом нельзя не видеть важного вклада в 
дело обеспечения и укрепления мирового порядка.

Отнесение основных принципов, в том числе принципа неприменения угрозы силой или самой силы против территориальной целостности или политической независимости государств, К разряду императивных норм свидетељствует о том, что понятие и действие императивных норм не ограничиваются сферой права международных договоров, как утверждают некоторые юристы-международники, а рвспространяются на все действия государств - односторонние и совместные - на международной аряне. Это мнение подкрепляется и тем, что в международном праве не закрепилось понятие "публичный порядок" (public order), которое, разумеется, относилосъ бы и к недоговорным взаимоотношениям государств. Понятие јus cogens восполняет данный пробел и должно толковаться как распространяющееся на все шаги и мероприятия государств в любых областях международных отношений и тем самым содействующее порядку в мировой политике.

Социяльные закономерности развития всемирньх отношений, в частности интенсивный рост и углубление международных связей, усиление взанмосвязанности и взаимозависимости различных акций государств, особенно в сфере безопвсности, в итоге привели к общему пониманию государствами того факта, что пределы свободного усмотрения государств должны бытъ поставлены в строгие, даже императивные, коридические рамки, выход за которые следует считать недопустимым и противозаконным. В противном случяе может быть нанесен ущерб не тољько интересам и правам других государств, но и всему мировому сообществу и мировому порядку.

В последнее время юристами-международниками стала обсуждатъся проблема возможности и способов возникновения новых императивных норм. При этом почему-то считается, что государство или группа государств обязаны сразу же указать, что предлагвемая ими международная норма вносится на рассмотрение конференции или иного нормотворческого органа именно в качестве императивной нормы. Для пояснения и обоснования такой точки зрения делаются ссылки на предложение в ходе работы III Конференции $\mathrm{OOH}$ по морскому праву группы развивающихся стран признать и одобрить принцип "общего наследия человечества" в качестве императивной основной нормы. Отказ конференции придать такой характер принииу "общего наследия человечеств" экстраполируется на будущее международное нормотворчество, и в силу этого делаются пессимистические прогнозы. Подобный взгляд обосновывается и соответствуюшим толкованием текста статьи 53 Венской конвеншия - праве международных договоров ${ }^{33}$. Но постановлекия данной статьи относительно императивных норм допускают и другое тол- 
кование. Оно, на наш взгляд, состоит в том, что императивными прнзнаются лишь нормы общего междунаропного права. Следовательно, новая норма должна снвчала стать общеприемлемой по своему содержанию и юридически обязательной для всех государств, то есть быть признанной как норма обшего международного права, а уж затем она может быть приэнана "международным сообществом государств в целом" как "норма, отклонение от которой недопустимо" (ст. 53 Венской конвенции). Причем концовка статьи повольно-таки четко говорит об этом, указвгая на то, что в дальнейшем такая норма может быть изменена "только погледующай нори, ой оощего международного права, носящей такой же характер"з4. Поскольку критерием истинности различных толкований и суждений является практика, то обратимся к ней.

Весьма показательна в этом отношении краткая история возникновения и становления новейшего основного принципа международного права - принципа всеобщего уважения прав человека и основных свобод для всех, без различия расы, пола, языка и религия. Его появление было обусловлено постановлениями Устава ООН относительно необходимости осуществления международного сотрудничества государств в области прав человека (n. 3 ст. 1, ст. 55). При этом никто из учредителей ООН не ставил перед собой задачу создания новых императивных норм общего международного правя. Однако в дальнейшем последовала разработка в рамках ООН целого ряда ныне широкоизвестных международных документов (Всеобщая декларация прав человека 1948 г., Международные пакты о правах человека 1966 г. и др.), которые привели в конечном счете к становлению и утверждению принципа всеобщего уважения прав человека. Он нашел свое подтверждение и во многих международно-правовых актах, принятых вне рамок ООН (Межамериканская деклврация 1948 г., Конвенция о правах человека 1969 г., Европейская конвенция о зашите прав человека и основных свобод 1950 г., Африканская хартия прав человека и народов 1981 г. и др.). Особое место среди них занимает Заключительный акт СБСЕ, в котором впервые была дана развернутая формулировка принципа и подчеркнуто "всеобшее значение" прав человека, уважение которых является "существенным фактором мира, справедливости и благополучия", необходнмых для обеспечения миропюбивых и дружественных отношений между государствами, что как раз и состввляет цель нового мирового порядка.

В международной практике не существует епиного документв, в котором содержался бы полный перечень основных прннципов и других императивных норм международного права. Это повышает роль и ответственность юристов-международников в установлении и 
выявлении четкого мнения международного сообщества относительно круга и объема таких принципов и норм. Однако к ним, несомненно, относится принцип всеобщего уважения прав человека. Об этом свидетещьтвуют, в частности, все те мероприятия и решения СБСЕ, которые бъ.ли приняты на последовавших после Хельсинкской встречи в 1975 году конференциях и совещаниях по вопросам человеческого измерения СБСЕ.

В документах, принятых в рамках СБСЕ, можно найти и указания на тескую связь принципа уважения прав человека с обеспеqением мирового порядка. Так, на Московском совещании Конференции по человеческому измерению (10 сентября - 4 октября 1991 г.) государства-участники подчеркнули, что вопросы, касающиеся "Прав человека, основных свобод", носят международный характер, поскольку соблюдение этих прав и свобод "составляет одну из основ международного порядка (курсив мой. - А. М.)"зs.

Государства - участники СБСЕ в последнее время постоянно указывают на тот факт, что обязательства в области прав человека, "человеческого измерения СБСЕ" представляют "непосредственный и законный интерес" для всех государств-участников "и не относятся к числу исключительно внутренних дел соответствующего государства". При этом подтверждается, что "защита прав человека, основных свобод" является жизненно важной основой всеобъемлющей безопасности ${ }^{36}$.

Эти новации, присущие общему международному праву, находят свое отражение и в теории международного права. Возникло даже новое понятие- "международная зашита прав человека", исследованию которого уже посвящено немало работ юристов-международников. К сожалению, в них стали встречаться и утверждения, что теперь индивид является субъектом международного права. В свою очередь (и, видимо, не без влияния подобных высказываний), в средствах массовой информации появились интервью и заявления отдељных юристов-государствоведов, в частности связанные с разработками проекта Конституции России, в которых прозвучало, что индивид отныне занимает особое, как бы равное с государствами положение в международных отношениях, может обращаться в любой международный суд, в том числе в Международный Суд ООН и Европейский суд по правам человека, и выступать там наравне с государством и против него. Однако, как известно, ни один из этих судов не признает таких прав за индивидами.

Конечно, государства могут в дальнейшем, если сочтут целесообразным, предоставить индивиду право обращаться в международное судебное учреждение, подобно тому как это было сделано в отношении компетенции Комитета по правам человека ${ }^{37}$. Мо- 
гут государства в дальнейшем признать 32 индивидом и свойство субъекта международного права. Но пока ито любые высказывания относительно международной правосубьектности индивидов не соответствуют действитељности. Более того, объективно они, вопре ки намерениям их авторов, могут послужить лишь ослаблению реальной защиты прав личности. В наши дни права человека немыслимы и не сушествуют вне государства, их непосредственная защита осушествляется государственными, административными и судебными учреждениями, действуюшими в государстве. Каждому человеку непосредственно доступны лишь те права и свобопы, которые предусмотрены законодательством государства. Отсюда и многие различия в объеме и круге прав и свобод, предоставляемых индивиду в разных странах. Нз этих непреложных фактов нсходила ООН, ставя перед собой задачу добиться всемирного признания и осуществления единых международных стандартов в области прав человекв во всех без исклкочения государствах.

Международной зашите прав чєловека присуща тенденщия $K$ еe постоянному расширению. Так, в свое время было признано необходимым распространить действие международного "гуманитарного права" на конфликты "немеждународного" характера. Актуальность данного решения подтверждается возросшим пислом межнациональных и иных столкновений и конфликтов, происходящих в ряде государств, в том числе образовавшихся на территории бывшего СССР. В понятии человеческого измерения СБСЕ также произошли изменения. Если раньше оно сводилосъ к вопросам, касающимся "прав человекв, основных свобод и контактов между людзми", то теперь в него вошли и вопросы "демократии и верховенства закона". Такое расширение было признано необходимым условием создания "стабиґьной обстановки прочного мира" в Европе ${ }^{38}$. Тем самым была еще раз подтверждена тесная связь между внутригосударственньми системами общественного порядка и международными. Такая взаимосвязь составляет существенную черту нового мирового порядка.

Для вористов-международников предстявляют несомненный интерес и те положения Декларации Хељьсинкской встречи СБСЕ на высшем уровне в 1992 году, в которых было подтверждено, пто принципы, изложенные в хельсинкском Заключительном акте 1975 года, "воплощают обязательства государств друг перед другом" и "не утратили своей силы". В ней было заявлено, что СБСЕ является региональным соглашением "в том смысле, как об этот говорится в главе VIII Устава Организации Объединенных Наций"з9. Эти четкие указания убедитељно свидетельствуют о признании всеми государствами - участниками СБСЕ юридического характера обязательств, содержащихся в соглашениях СБСЕ. Вспоминается в связи С 
этим то некоторое замешательство среди юристов-международников, которое было вызвано непривычным наңменованием хельсинкского соглашения 1975 года Заключителъным актом. Этот термин был применен фактически в результате усилий дипломатов ФРГ, которые стремились принизить правовое значение принципа "нерушимости границ", и английских дипломатов, старавшихся избежать процедуры ратифнкации первого хељьинкского соглашения ${ }^{40}$.

Если политическая подоплека этих усилий вполне объяснима, то юридический их смысл до сих пор остается загадкой. Ведь к тому времени уже быля осуществлена кодификашия права международных договоров в Венской конвенции 1969 года, язык которой настолько ясен, что доступен каждому, тем более дипломатам. В ее начальных постановлениях (ст. 2) прямо поясняется, что "договор" означает "международное соглашение, заключенное между государствами в письменной форме", незввисимо от того, содержится ли такое соглашение в одном или "нескольких связанных между собой документах, а также независимо от его конкретного наименования (курсив мой. - A.M.)".

Что же касается согласия государства на обязательность для него договорв, то такое согласие может быть выражено "подписанием договора" или "любым другим способом, о котором условились" (ст. 11), а не только ратификацией договора. Однако, несмотря на это, отдельные юристы-международники стали утверждатъ, что хељсинкский Заключительный акт- это "ненормативный акт"41. Другие попытались распространить на характеристику этого акта свою концепцию "политических норм". И в том, и другом случве отрицался, в сушности, международно-правовой характер принципов и норм Заключительного акта, причем даже без учета имевших место в тот период заявлений государств - участников СБСЕ, в частности CIIA и Канады, о юридической силе и обязательной применимости к их взаимоотношениям принципа нерушимости границ. Интересно, как поступят сейчас эти юристы, когда все участники СБСЕ подтвердили, что принципы, изложенные в Заключительном акте, составляют их юридические обязательства, а СБСЕ в целом расцекивается ках международное региональное соглашение, то есть как международный договор (по смыслу Венской конвенции 1969 г. и гл. VIII Устава ООН).

В период "холодной войны" многие западные страны не стремились признать международно-правовой характер обязательств государств - участников СБСЕ по Декларации принципов и иным соглашениям, содержвщимся в Заключительном акте 1975 годв. Однако ныне в рамках СБСЕ появилась и нарастает новая тенденция. Все чаще государства - участники СБСЕ стали проявлять озабочен- 
ность о соблюдении соглашений СБСЕ, подчеркивать их обязательную силу и принимать меры по их неуклонному исполнению, создавая в зтих целях особые междунарощные органы и механизмы контроля, инспекции, согласования и рвзрешения споров. Юридическая природә всех этих мер не вызывает уже сомнений и служит новейшим подтверждением международно-правового характера норм и обязатељьт, содержашихся в соглашениях СБСЕ.

Обязатељьость права, в том числе междунаропного правя, представляет собой то необходимое качество и свойство права, которое отличает его от других регуляторов общественных отношений. Конечно, обязательность международного права предполагает наличие ответственности 38 его нарушения и возможность применения принуждения для подавления и устранения любой угрозы миру, любого нарушения мира или акта агрессии.

Для повышения уровня юридической обязатељности принципов и норм международного права было уже немало сделано международным сообществом, которое еще в 1945 году провозгласило свою решимость "создать условия, при которых могут соблюдаться спреведливость и уважение к обязательствам, вытекаюшим из договоров и других источников международного права" (преамбула Устава ООН). В этих целях прежде всего было осуществлено преобразование приншипов меж дународного права в общепризнанные и общедемократические основные нормы. Затем им был придан юридический характер императивных норм јus cogens. Теперь уже в доктрине и практике мехдународного права считается недопустимым существование норм, которые бы не соответствовали его основным приншипам. В результате этого появинось и утвердилось новое свойство мехуународного права - шрндтуесквя согласованиость систей всех

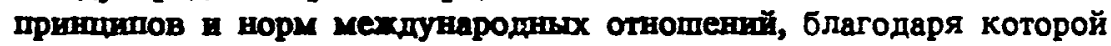
дальнейшее развитие мирового порядка возможно лишь по пути социального прогресса, дальнейшего укрепления ненасильственных, нормальных и дружественных отношений между всеми государствами.

Расширились виды и формы международно-правовой ответственности государств ${ }^{42}$, их практическая реализация в процессе мирного урегулирования конфликтов и споров между государствами. Повышается обязательность обращения государств в этих целях в различные международные органы и судебные учреждения. Что касается принуждения, то прежде всего следует подчеркнуть, что оно весьма многообразно и не сводится, как и во внутригосударственных системах права, лишь к пействиям правоохранитељьых органов. Мнение международного сообщества государств в целом, мировое общественное мнение да и мнение общественных кругов госу- 
дарства относитепьо противозаконности тех или иных внешнеполитических акций государств, несомненно, служат мощными факторами принудитељього воздействия на поведение того или иного государства на междунаропной арене. Не случайно междунаропное право считается более соблюдаемым, чем внутригосударственное право, которому известна развитая система карательных мер в отношении правонарушений и преступлений. Не так уже часты и грубейшие нарушения международного права по сравнению свнутренним. Повседневная жизнь государств, их взанмоотношения и сотрудничество в самых разнообразных сферах мехдународных отношений все-таки в основном осуществляются в рамках международного права. Этот факт не могут не признать даже скептики, отрицающие кридическое и практическое значение международного права ${ }^{43}$.

Вместе с тем следует признать, что необходимость в существовании и применении действий и мер принуждения в отношении угрозы миру и нарушений мира весьма актуальна. Такого рода дамоклов меч должен висеть над теми государствами, которые все еще уповают на силу в своей внешней политике. Агрессия Ирака против Кувейта показала, что в основе ее лежал и расчет на безнаказанность в условиях конфронтации Запад - Восток и разноречий между Югом и Севером. Политический просчет руководства Ирака состоял в том, что оно никак не ожидало решительного выступления против него международного сообщества. Совет Безопасности ООН в данном случае прибег к помощи вооруженных сил СШІА и некоторых друтих государств. Но, видимо, настала пора всем государствам серьезно задуматься о необхопюмости эффективного осушествления полномочий и функций Совета Безопасности ООН, которые относятся к сфере осуществления принуждения со стороны $O O H$ и нашли свое закрепление в Уставе ООН, в чвстности в его главе VII. В этих постановлениях Устава ООН отражен тот потенциал, который еще жцет своей реализачия в целях даљьнейшего укрепления мирового порядка.

Новейшие тенденщи в мировой политике и международных отношениях подтверждают, что сообщество государств рассматривает международное право как олицетворение того мирового порядка, который должен действовать на нашей планете. Аљьтернативы мехдународному праву, создававшемуся человечеством в течение столетий, нет.

1 Cx. 3a pyoercar - 1991. - No 21. - C. 8-11.

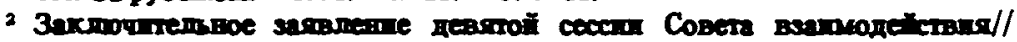
Правда. $-1991 .-14$ ироня.

C. 4.

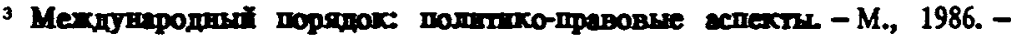


- CM., kampromep, International Law: A Contemporary Perspective. Studies on a just World Order. - No 2. - Westriew Press, 1985.

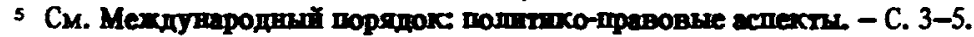

- Cx. Falk R. The End of World Order//Esays on normative international relations. - N.Y., 1983; Yalem R. The Concept of World Order//The Year Book of World Affairs. - Vol. 29. - L., 1975. - P. 321-336.

7 Ливап P.3. Современная теория права. Краткий очерк. - М., 1992. C. 8 .

8 Tar ze - C. 22.

- International Court of Justice. Reports - 1980. - P. 44.

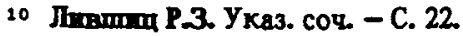

11 Tar ze. - C. 22-23.

12 CM. Mosler H. The International Society as a Legal Community. - Alphen aan den Rijn, 1980.

13 Cx. Weil P. Towards Relative Normativity in International Law?//American Journal of International Law. - 1983. - Vol. 77. - P. 413-442.

14 Мовтан A.II. Oрганизация Объединенных Наший и мехдународный правопорядок (к 40-летию ООН)//СОв. ежегодник международного права. 1985. - M., 1986. - C. 21. 1990. - C. 71 .

15 Еватов B.I. Международное сообщество и правопорядок. - Кнев,

16 Ушахов Н.A., Эапп М.Л. Современный международный правопорядок//Межпународный порядок: политико-правовые аспекты. - С. 83.

17 Tax Ire.

18 International Court of Justice. Reports. - 1949. - P. 178.

19 Мегцународное право/Отв. ред. Г.И. Тункин. - М., 1982. - С. 63.

20 Кодосов О.М. Международньй правопорядок в космосе//Международный порядок: политико-правовые аспекты. - С. 122.

21 CM. Reriew of the Multilateral Treaty-Making Process. UN, 1985. - P.16.

22 International Herald Tribune. - 1985. - Oct. 21.

${ }^{23}$ С.. Мег дународное право/О тв. ред. Г.И. Тункин. - С. 59.

24 Tan zxe. - C. 43.

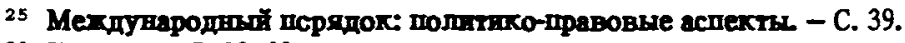

26 Tan ze. - C. $23,39$.

27 Нзвествя - 1992. -7 дек.

28 Tam re.

29 См., например, Броущш Я. Международное право (в двух хнигах). M., 1977; Аречага X. Современное международное право. - М., 1983.

${ }_{30} \mathrm{Cм}$. Основнте приниашы мехиународного права//Курс международного права (в семи томах). - Т. 2. - М., 1989.

${ }_{31}$ Мехдународное право в документах. - М., 1982. - С. 11-12.

32 См. Мовчан А.II. Кодификашия и прогрессивное развитие междунвродного права. - М., 1972. - С. 25-28.

${ }^{33}$ См. об этом Cassese A. International Law in a divided World. - Oxford, 1990. - P. 175-179; Danilenko G.M. International jus cogens: Issues of Law-Making// European Journal of International Law. - 1991. - Vol. 2. - No 1. - P. 42-65.

34 Мег дународное право в документах. - C. 87.

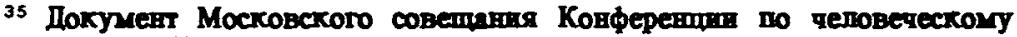

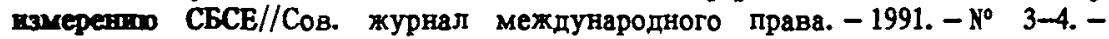
C.117. 


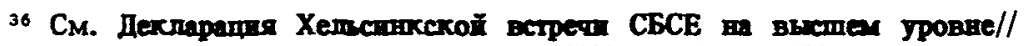
Московский журнал мехдународного права. $-1992,-\aleph^{\circ} 4 .-$ С. 181.

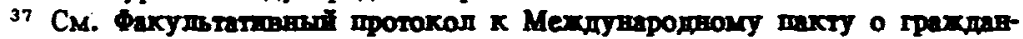

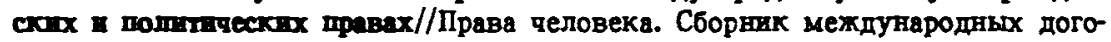
воров. - OOH, 1983. - C. 20-21.

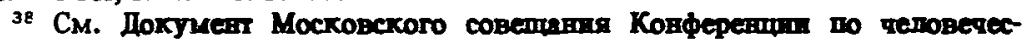
кoary घзмеренin CBCE. - C. 116-117. $181,184$.

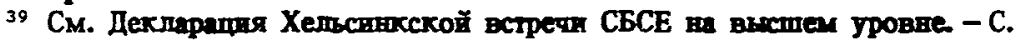

$40 \mathrm{C}_{\mathrm{M}}$. Russel H. The Helsinki Declaration: Broabdingnang or Liliput?//American Journal of International Law. - 1976. - Vol. 70. - P. 242-272.

41 Ca. Weil P. Op. cit. - P. 414.

42 CM. Internationul Crimes of State. Berlin - New York, 1989. Draft Articles on State Responsibility, Art. 19//Yerbook of pthe International Law Commission. - Vol. II. - UN, 1976.

43 CM. Vereshchetin V.S., Danilenko G.M. Cultural and Ideologial Pluralism and International Law//German Yearbook of International Law. - 1986.- Vol. 29. P. 56-67. 